\title{
Expulsão do paraíso
}

\author{
Armando de Melo Lisboa \\ Departamento de Economia da Universidade Federal de Santa Catarina (Ufsc)
}

Recebido: 15/11/2015 Versão revisada (entregue): 08/02/2016 Aprovado: 15/02/2016

\begin{abstract}
Resumo
Este trabalho visa descortinar o período de germinação da reflexão econômica moderna, a qual no final do mesmo desabrocha, apresentando-se, primeiramente, como "Aritmética Política", cálculo a serviço do Rei, um saber para o Estado. Aqui veremos o desenvolvimento da oposição entre o homem e a cidade, entre o interesse privado e o da polis, que já se manifestava no mundo grego. Neste contexto de rupturas que levam do tomismo/holismo antigo ao atomismo/individualismo moderno, o econômico se desincrusta do tecido social e assume sua face atual, impondo-se a conflituosa dinâmica em que o enriquecimento privado se emancipa e contrapõe-se ao interesse público. Assim, expulsa do Paraíso - não por nenhum anjo transcendente, mas pelos desdobramentos fortuitos da história humana - e presa à vida de escassez (conceito derivado da concepção econômico-teológica que professa a insaciabilidade infinita do desejo humano), a economia vai se apresentar como ciência desoladora. É buscando responder às crescentes tensões aqui geradas, e reconciliá-las, que Adam Smith erguerá sua "Riqueza das Nações", centrada no metafórico e epifânico conceito da mão invisivel. Entre os fatores que impulsionaram este processo, aqui se examinam três deles.
\end{abstract}

Palavras-chave | Economia moderna; Estado; individualismo; interesses privados; riqueza privada.

Código JEL | D31; B50; P17.

\section{EXPULSION FROM PARADISE}

\begin{abstract}
This work aims to uncover the germination period of the modern economic thought. At the end of this period it appeared as "Politics Arithmetic", a calculation to the King's service, knowledge for the State. It shows the development of the opposition between man and the city, the private interest and the polis, which has already manifested in the Greek world. In this context of ruptures that lead of Thomism/holism to atomism/modern individualism, the economy leaves the social web and takes its present face, imposing the dynamic conflict in which the private enrichment is emancipated and opposed to the public interest. Thus, expels from Paradise - not by any transcendent angel, but by fortuitous consequences of human history - and attached to the life of scarcity (a concept derived from the economic-theological conception that professes the infinite insatiability of human desire), the economy will perform as dismal science. It seeks responding to the growing tensions generated, and to reconciling them, that Adam Smith will
\end{abstract}


lift his "Wealth of Nations", centered on the metaphorical and epiphanic concept of the invisible hand. Among the factors driving this process, three of them will be examined here.

Keywords | Individualism; modern economy; private interests; private wealth; State.

JEL-Code | D31; B50; P17.

\section{EXPULSIÓN DEL PARAÍSO}

\section{Resumen}

Este trabajo tiene como objetivo desvelar el período de germinación del pensamiento económico moderno. Al final de este período el mismo apareció como "Aritmética Política", un cálculo al servicio del Rey, un conocimiento para el Estado. Aquí vamos a ver el desarrollo de la oposición entre el hombre y la ciudad, entre el interés privado y la polis, que ya se ha manifestado en el mundo griego. En este contexto de rupturas que lleva del tomismo/holismo al atomismo/individualismo moderno, la economía sale del tejido social y toma su aspecto actual, imponiendo la dinámica conflictiva en la que se emancipa el enriquecimiento privado y oponiéndose al interés público. Por lo tanto la expulsión del Paraíso - no realizada por ningún ángel trascendente, sino por los acontecimientos fortuitos de la historia humana - y unida a la vida de la escasez (un concepto derivado de la concepción económica-teológica que profesa la insaciabilidad infinita del deseo humano), la economía va a presentarse como una ciencia desoladora. Buscando responder a las crecientes tensiones generadas, y reconciliarlas, Adam Smith construye su "Riqueza de las Naciones" centrado en el concepto metafórico y epifánico de la mano invisible. Entre los factores que impulsan este proceso, tres de ellos se examinarán aquí.

Palabras-clave | Economía moderna; Estado; individualismo; intereses privados; riqueza privada.

Código JEL | D31; B50; P17.

\section{Introdução}

"Nós, espanhóis, sofremos de uma doença do coração da qual o ouro é o único remédio". (Cortez)

"A economia política enquanto disciplina especifica não se aplica à família ou às pequenas comunidades, lugares de cooperação e reciprocidade. Ela começa justo ali onde terminam a cooperação e a reciprocidade”. (A. Gorz)

"A economia não é apenas um instrumento de regulamentar a produção e o consumo, é também um meio eficiente de regulamentar o comportamento bumano". (K. Mannheim) 
Este trabalho visa descortinar o período de germinação da reflexão econômica moderna, a qual desabrocha, no final do transcurso, primeiramente como "Aritmética Política", cálculo a serviço do Rei, um saber para o Estado. Veremos o desenvolvimento da oposição entre o homem e a cidade, entre o interesse privado e o da pólis, que já se manifestava também no mundo grego ${ }^{1}$.

Neste contexto de rupturas que levam do tomismo/holismo antigo ao atomismo/individualismo moderno, o econômico se desincrusta do tecido social e assume sua face atual, impondo-se a conflituosa dinâmica em que o enriquecimento privado se emancipa e contrapõe-se ao interesse público. Assim, "expulsos do Paraíso" (ROBBINS, 2012, p. 14) - não por nenhum anjo transcendente, mas pelos desdobramentos fortuitos da história humana - e presos à vida de escassez (conceito derivado da concepção econômico-teológica que professa a insaciabilidade infinita do desejo humano), a economia vai se apresentar como "ciência desoladora" (dismal science).

É buscando responder aos crescentes e disruptivos tencionamentos aqui gerados, e reconciliá-los, que Smith erguerá sua magna obra "Riqueza das Nações", centrada no metafórico e epifânico conceito da "mão invisível".

Entre os inúmeros fatores que impulsionaram este processo, três aqui destacamos:

\section{(i) A irrupção do medo do outro}

"Pobre é aquele que não tem ninguém; pobreza é solidão". (provérbio Serere)

"Os monges encontraram o segredo do ócio verdadeiro não como liberação do trabalho, mas como liberdade dentro do trabalho". (Mumford)

\footnotetext{
${ }^{1}$ Nossa brevíssima exposição com tão larga temporalidade pode trair o leitor e levá-lo a pensar a evolução histórica como um processo linear ou o resultado inelutável de um imperativo histórico qualquer. Nada mais falso. A busca da compreensão da mesma apalpa dinâmicas incoerentes e aleatórias, nas quais os elementos "mais importantes" muitas vezes são contingentes, peculiares e ambíguos. Esta propriedade dionisíaca da vida foi assim captada por Keynes: "O inevitável nunca acontece. É o inesperado sempre". Ou seja, fenômenos sociais se enquadram melhor em termos de tertium datum e da lógica contraditorial vislumbrada por Nicolau de Cusa em 1431. Não há fatalismos, nem plena autonomia, pois "a história é um palco onde forças que estão sob controle humano lutam e cooperam com forças que não estão", sugere Tawney (1971, p. 260). A sociedade humana, portanto, se molda na irresolúvel antinomia entre determinismo e liberdade, estando longe de comportar-se como um mero jogo de bilhar da física newtoniana. Ela está prenhe de devir, possiblidade, desejo. Nela sequer existe homogeneização, mas diferenciação, mesmo diante do processo de integração global cada vez mais avassalador.
} 
No oeste da Europa, os 1000 anos entre a queda do Império Romano até cerca do século XVI foram marcados pelas tentativas das pessoas se governarem diretamente em pequenas comunidades, com a Igreja operando a macro-política dentro do regime de cristandade então vigente. O fracasso desta experiência fará a política retornar com "uma forma virulenta que a Antiguidade não conhecia", advoga Milbank (1995, p. 557).

A partir do século XI, com a irrupção das cidades livres e das universidades, especialmente na península italiana as urbes convertem-se em repúblicas independentes, e voltam a ocupar a proeminência tida no mundo antigo. Recuperando o ideal antigo do bem comum e do bom governo, descortina Le Goff (1998, p. 102) ${ }^{2}$ que "a cidade medieval foi, mais do que hoje, um campo de experiências sociais e políticas".

Clérigos cristãos, no século XII, descobrem na Península Ibérica, então muçulmana, o grosso dos escritos de Aristóteles perdidos para o Ocidente por mil anos. O Ocidente então reencontra a herança clássica grega pelas mãos árabes que as tinham preservado, aplicado e aprimorado. Traduzidos avidamente para o latim por equipes multiculturais de sábios, estes textos provocaram uma fermentação cultural sem precedentes, uma revolução na Europa que alterou para sempre o modo de pensarmos a natureza, a sociedade; Deus constituindo um dos alicerces da renascença e do humanismo.

A filosofia de Aristóteles revirava a fundo o agostinismo então dominante. Agostinho, em "A cidade de Deus", representa a sociedade política como uma ordem determinada por Deus e imposta aos homens, decaídos com o pecado original de Adão, como remédio para seus pecados. Adão (que significa "homem") pecou por romper o vínculo vital com o divino ao agir desobedecendo-o. Proclama Fromm (1986, p. 37) que esta desobediência funda "O primeiro ato de liberdade, o primeiro ato humano". Por esta ousadia, fomos expulsos do paraíso e, impotentes diante da potência demoníaca do mal (uma vez que afastados de Deus), condenados a obedecer a outros, às relações heterônomas emanadas do Estado. Encarnando uma autêntica metafísica da ordem e da autoridade, a cidade terrestre, portanto, era apenas uma transição para a vida eterna, a ser vivida na cidade divina.

Já Aristóteles trata a polis como uma criação puramente humana, destinada a atender fins estritamente mundanos. Sendo a condição do homem naturalmente social, como o estagirita enunciou, a fábula cristã da necessidade de autoridade terrena como elixir providencial para neutralizar e reprimir supostos impulsos

\footnotetext{
${ }^{2}$ Relata ainda Le Goff (1998, p. 90) que, em 1260, Alberto, o Grande, pregou durante uma semana uma série de sermões tendo a "cidade" como único tema, dos quais partiu de uma frase de Cícero: "uma cidade não é constituída de pedras, mas de homens, de cidadãos".
} 
destrutivos fica inecessária. Convencidos de que eram naturalmente bons e capazes de virtude, os homens deixam de "pensar que Deus havia aprovado sua submissão aos príncipes para reprimir sua maldade" (SAHLINS, 2011, p. 78), e se tornam cidadãos ativos.

Aos poucos, o sentido da história humana se modifica drasticamente. Numa economia essencialmente rural, o lento crescimento demográfico gerou um progresso material continuo na Europa da época, pois operava em território de pequena densidade demográfica. Nas cidades, o comércio (a começar pelo de comida) e as manufaturas proporcionam fontes de riqueza e propiciam a formação de uma burguesia, ou seja, uma classe de pessoas que aufere renda destas atividades. Tendo muito mais necessidade de dinheiro do que o campo, a cidade suscita o surgimento do banqueiro. Desinibindo-se, as práticas usurárias e especulativas recebem ímpeto e enfrentam escrúpulos e proibições. Novas hierarquias, agora com base no dinheiro e mercados, se estabelecem. Em tal estufa desponta um novo albor de prosperidade econômica que parece negar tudo que fora contido pelas virtudes cristãs. O mito de progresso se instala no imaginário coletivo.

Durante esses primeiros séculos do milênio, a indigência não existia como problema social, pois na sociedade medieval obrigações de solidariedade e partilha faziam os senhores "abrir seus celeiros aos necessitados"3. A partir do século XII, com a pregação dos frades mendicantes "impôs-se a ideia de que, para agradar a Deus, os ricos deveriam partilhar com os pobres", e adiou-se mais uma vez a caça aos mesmos.

Às vésperas do século XIV a Europa já está superpovoada. O excesso da população rural ruma para as cidades. Nelas os carentes são socorridos, mas o indigente torna-se preocupação pública: a riqueza, agora móvel, fica vulnerável uma bolsa ou um cofre se rouba mais fácil que um pedaço de terra. "A maioria das famílias camponesas não possui terra suficiente para subsistir, e frequentemente falta pão nas cidades". Ainda assim, a moral impedia de excluir os pobres, não havendo ascensão de medo diante deles, o que não ocorria com leprosos e judeus, os quais eram trancafiados e isolados em guetos. A pobreza da época se diluía no corpo social. Não existia nas urbes "uma segregação entre bairros abastados e os outros. Pobres e ricos moravam nas mesmas ruas, nas mesmas edificações", facilitando o sistema caritativo. "Os miseráveis ainda não formavam um grupo coeso, uma classe perigosa da qual fosse preciso proteger-se, cercando-a, expulsando-a".

No século XIV adveio a catástrofe: a peste negra, dizimando em meses talvez um terço da população. "Amplificado pelo retorno periódico da epidemia e agravado pelas convulsões políticas da época", o choque fez instalar-se na consciência "uma

\footnotetext{
${ }^{3}$ Neste e nos dois próximos parágrafos sigo a análise de G. Duby (1993).
} 
equivalência entre miséria, agressividade e perigo", moldura para a exclusão dos pobres. Na Europa então se inicia a sua marginalização ${ }^{4}$.

\title{
(ii) Desencantamento do mundo, sacralização da economia ${ }^{5}$
}

\author{
"É o destino habitual de novas verdades comecarem como heresias e \\ terminarem como superstições". (T. H. Huxley) \\ "Nada impede que essencialmente o poder de toda sociedade seja um poder \\ espiritual”. (G. Lukács) \\ "O nome do deus mudou, mas a invocação continua idêntica". (Maffesoli)
}

Ao dessacralizar a natureza, o surgimento do Cristianismo propiciou uma base ontológica favorável ao advento do capitalismo. Isto permite despojá-la das crenças que a protegiam e cultuavam, abrindo caminho para a intensificação de sua exploração e a irrupção de uma nova fé, no progresso e desenvolvimento. Se Deus se distingue da natureza, o ser humano, como imago dei, também é visto apartado da mesma. Assim a teodiceia cristã rompe com as demais religiões que advogavam a união do ser humano com a natureza ${ }^{6}$. Esta crença forjará a

${ }^{4}$ Em 1993 Duby antecipou que o século XXI seria o do fluxo migratório irreprimível em direção a regiões prósperas, alertando que as notícias e previsões "suscitam medo" e alimentam a "tentação de se fechar, de se proteger, o medo do outro, seja ele quem for, julgado delinquente a priori, e que deve ser contido, impedido". Este dilema "é o mais nocivo. Ele mina em profundidade nosso sistema de valores. Envenena nossa civilização. Enfraquece-a" (1993, p. 229). O presente drama dos refugiados e a crescente xenofobia questionam o conceito de "Estado-nacional" e desnudam o quanto anacrônico e perigoso é continuar a defender hoje a ideia de "projeto nacional" para os países. Neste sentido, no tópico (iii) demonstraremos como este sonho nacional-estatista já nasceu ofidicamente limitado. A agenda neste início do século XXI já não é mais a da formação da nação, com sua pauta de unidade e uniformidade. $O$ “processo de 'formação' se encerrou - ainda que não tenha se completado", aponta Nobre (2012, p. 77), pois no mundo das redes tanto o Estado não tem mais um papel primordial (a geopolítica responde cada vez mais a marcos plurais e multiculturais), quanto os processos de modernização econômica são muito velozes e desterritorializados, isto é, não restritos a se condensar e articular apenas em termos tangíveis e de valor. Diante da crise do hífen que uniu o Estado e a nação, uma certa ideia de Estado deve mudar e abrir-se para a cosmopolítica polifônica, mas isto já é assunto de um próximo paper.

${ }^{5}$ Como desenvolvi este tema em texto recente (LISBOA, 2014), farei aqui uma breve discussão.

${ }^{6}$ Talvez a grande lição de Darwin foi mostrar "que os humanos são como os outros animais", desvelando que "o pecado capital do cristianismo" é afirmar a nossa diferença para com as demais espécies, conclui Gray (2009, p. 20). Também Waal (2010, p. 291) observa isto. Após demonstrar a "continuidade emocional entre o homem e os outros animais", ele assinala que 
metafísica ocidental que pressupõe uma "oposição entre natureza e cultura", lamenta Sahlins (2011, p. 19).

Concedendo ao homem poder sobre a natureza, o pensamento científico moderno expressa a continuidade e secularização do pensamento religioso que concebeu um Deus acima da natureza. "A transcendência de Deus é simplesmente transferida ao homem” (NEGRI; HARDT, 2001, p. 109).

Do mesmo modo, a ciência da economia que irrompe com o Iluminismo é apenas a forma imanente que transmuta, vicariamente, o escatológico plano providencial da economia da salvação, governo divino do mundo. Ela possibilita restabelecer a ordem transcendente, agora de forma mais débil e relativa, mas evitando o autogoverno dos homens que aos poucos se redescobriam criadores de si próprios e artífices do seu destino, como vislumbrou, em 1486, Pico della Mirandola. Esta primordial voz moderna do homo faber declarou que a nossa dignidade advém do homem, como "escultor da própria imagem" e dotado do "livre arbítrio", poder "ser o que quiser" (MIRANDOLA, s.d., p. 40). Ainda mais subversivo é o brado de Etienne de La Boetie, que em 1548 mordazmente incitou os povos a desobedecerem ao príncipe, revelando que seremos livres quando decidirmos não mais servir (1986, p. 29). Viviam-se então tempos de Reforma, tempos de Descobrimentos, tempos de Utopia, tempos de escolhas e ideias cada vez mais iconoclastas e que dotam o ser humano de asas.

Ao pressupor que a economia funciona mecânica e independentemente da vontade dos homens ${ }^{7}$, "a economia política constitui-se como racionalização social

somente as religiões judaico-cristãs "colocam o homem num pedestal, afirmando ser ele a única espécie dotada de alma". Isto se explica por advirem de sociedades que não tinham "animais que pudessem servir-lhes de espelho", pois eram nômades no deserto. Como o Ocidente sempre teve uma postura imperial e de barbarização dos povos ditos "primitivos", nunca compreendeu suas cosmologias, as quais sempre ensinaram esta lição darwiniana, conforme hoje elucida Viveiros de Castro e sua tese do "perspectivismo ameríndio".

${ }^{7}$ Por trabalhar com regularidades estatísticas (vale lembrar a origem deste vocábulo, fixado etimologicamente: números exigidos pelo Estado para dar maior eficiência ao seu poder) e repetições demonstráveis de fatos reais, os aritméticos políticos, ontem e hoje, supõem que a análise econômica desvelou leis e normas do comportamento social, como se o homem fosse um animal que apenas se comportasse de forma condicionada. Ao formar a opinião pública, a ciência econômica acaba definindo o padrão de comportamento que a sociedade espera dos indivíduos, pois toda ação espontânea e reação inusitada gera desvios que fogem da uniformidade estatística, tendendo a ser desincentivada, obliterando a liberdade e a plena individualidade, bem como as condutas não utilitaristas. Guerreiro Ramos (1981, p. 54) descreve com precisão este ofuscamento do potencial da vida humana associada, por ele traduzida na categoria "síndrome comportamentalista". Esta surge do esforço das instituições da sociedade de mercado em modelar a conduta social apenas conforme critérios de economicidade (tipo de "racionalidade" que sustenta ser o tempo de sono um desperdício...). Como "o bom cidadão obedece a prescrições externamente derivadas", os membros da mesma interiorizam padrões cognitivos robotizados, desprovidos de senso ético. A natureza disciplinar da economia 
da oikonomia providencial", arremata Agamben (2011, p. 306), uma vez que o homo economicus é apenas a naturalização do pecado original sob a forma do interesse material pessoal, e o capitalismo (ou o comunismo, a depender do gosto) é a sua redenção. Ou seja, o paradigma econômico é, na sua essência, um paradigma teológico secularizado.

Ciente disto, a primeira corrente moderna que se apresentou como "os economistas" também se auto-identificava como uma "seita". Todavia, mais conhecida pelo título de "fisiocracia", ela defendia, como é sabido, que a economia humana faz parte de uma "ordem natural", de caráter teleológico, à qual a sociedade deve ajustar-se. O melhor governo possível é aquele que segue as "leis justas e perfeitas" instituídas pelo "Autor da natureza", expressão que será usual com Adam Smith na "Teoria dos Sentimentos Morais".

moderna está gravada nos seus textos fundacionais, como em William Petty, por muitos considerado "O pai" desta forma de pensar. No século XVII ele praticamente inaugura o controle biopolítico característico da modernidade ao propor que as massas de pobres então recém-formadas (ao serem expulsas de suas terras e posses), quando sem empregos sejam amparadas, mas que em contrapartida trabalhem, nem que seja "para a edificação de uma pirâmide inútil" ou "carregando pedras", pois "isso manteria suas mentes disciplinadas e obedientes e seus corpos capazes de suportar trabalhos mais pesados quando houver necessidade" (1983, p. 23). Esta defesa das Poor Law desnuda os seres humanos de suas capacidades auto-organizativas, e será prenhe de consequências, definindo a economia como pura técnica de poder codificada para produzir indivíduos socialmente normatizados conforme um padrão disciplinar. Hannah Arendt, em "A condição humana", não hesita em se pronunciar contra esta normalização advinda da racionalidade econômica utilitária, constatando tristemente "a perda da experiência humana" por ela acarretada. "O problema das modernas teorias do behaviorismo não é que estejam erradas, mas sim que podem vir a tornar-se verdadeiras, que realmente constituem as melhores conceituações possíveis de certas tendências óbvias da sociedade moderna. É perfeitamente concebível que a era moderna - que teve início com um surto tão promissor e tão sem precedentes de atividade humana - venha a terminar na passividade mais mortal e estéril que a história jamais conheceu” (1989, p. 335). A deformação da existência humana é tal que Keynes, com a autoridade de quem produziu uma "Teoria Geral da Moeda", proclama que o amor ao dinheiro haverá de deixar de ocupar lugar de importância no código moral e retornar aquilo que ele é: um padrão mórbido de sociabilidade, uma tendência semicriminosa e semipatológica que "costumamos confiar a um especialista em doenças mentais". Iván Illich, em sua clássica crítica dos efeitos contraprodutivos da extrema programação da vida moderna, demonstrou que ela é geradora de crises e ineficiências, ao invés dela ser portadora de progresso. Hirschman, assumindo o poder manipulativo do economista, que traduz como "possibilismo", diz que "o meu objetivo não é fazer previsões de tendências. Antes, dedico-me a procurar entender o que é possível que aconteça e a despertar o interesse das pessoas sobre isso" (2000, p. 74). Contemporaneamente, um alerta com relação à cegueira dos economistas para com a aleatoriedade fractal e os grandes desvios foi exposta por Nassim Taleb (em "A lógica do cisne negro" e "Antifrágil").

${ }^{8}$ Quesnay, citado por Kuntz (1982, p. 107). 
As leis celestiais do mercado e o sacrossanto dinheiro são cotidianamente incensadas por uma espécie de teologia econômica pura, a da liberalização. Garante Marx que a sociedade burguesa, "que libertou tão formidáveis meios de produção e troca, é como uma feiticeira incapaz de controlar os poderes ocultos desencadeados pelo seu feitiço" (Apud BERMAN, 1987, p. 99). Como veremos a seguir (tópico iii), há uma grande proximidade entre essa ciência nascente e as práticas ocultistas: "a economia moderna é uma continuação da alquimia por outros meios" (BINSWANGER, 2011, p. 86). Aliás, Marx e Engels não cansaram de repetir o postulado da teoria cientificista de Saint-Simon de que no futuro "o governo dos homens seria substituído pela administração das coisas".

Exaltando graças às forças do capital e do mercado, eis que surge o indivíduo burguês, extremamente competitivo e solipsista, vivendo apenas em função dos seus propósitos privados (um autêntico idiota - do grego idiótes, aquele que se fecha na sua privatividade e se recusa à política). Presume-se em liberdade, mas é uma liberdade tacanha e temerosa, pois "homens isolados são impotentes por definição". A solidão "prepara os homens para o domínio totalitário", diz Arendt. Como "o terror só pode reinar absolutamente sobre homens que se isolam uns contra os outros [...], uma das preocupações fundamentais de todo governo tirânico é provocar esse isolamento" (2011, p. 526; 530)․․

\section{(iii) Armas e dinheiro no advento do absolutismo e do Estado-Nacional}

"Aux armes, citoyens, formez vos bataillons, marchons, marchons! Qu'un sang impur abreuve nos sillons!" 10 (La Marseillaise)

"Não pode haver boas leis onde não há boas armas, e onde há boas armas deve haver boas leis". (Maquiavel)

"Em alguma parte há ainda povos e rebanhos, mas não entre nós, irmãos meus, entre nós há Estados. Estado? O que é isso? Prestem atenção, vou falar para vocês da morte dos povos. O Estado é o mais frio de todos os monstros frios: mente friamente, e esta é a mentira que surge de sua boca: 'Eu, o Estado, sou o povo"". (Nietzsche)

\footnotetext{
${ }^{9}$ Sobre este ponto, Maffesoli (2001, p. 243) sugere que o totalitarismo deriva do "processo de atomização" e da "perda de solidariedade", "é a resposta desvairada" advinda da organização economicista centrada no individualismo.

10 “Às armas, cidadãos, formai vossos batalhões, marchai, marchai! Que um sangue impuro banhe o nosso solo!"
} 
Com a introdução das armas de fogo, pela primeira vez na história a cidade tornase obsoleta como forma defensiva. Corrói-se sua importância política, pois a sobrevivência obriga a construção de pactos e alianças maiores, moldando a emergência do Estado absolutista, antessala do Estado-Nacional.

Adam Smith (1983, p. 163) acentuará que os avanços em tecnologia militar favorecem "à nação que pode gastar mais", invertendo a desvantagem dos antigos países ricos em se defender contra os pobres. As despesas de guerra ficam mais pesadas, tornando-se "uma indústria do Estado"11, e os que podem mobilizar grandes contingentes são mais favorecidos. Muda a natureza da guerra.

O príncipe e o burguês entrelaçam-se sinergicamente, propiciando a Revolução Comercial e a constituição do sistema mercantil fundado no comércio de longa distância e na ampliação espacial do mercado, emoldurado agora pelas fronteiras alargadas do Estado. Disto decorre a monetarização cada vez mais completa da economia, e o advento da determinação dos preços pelo mecanismo do mercado, os quais deixam de ser comunitária e politicamente regulados. Progressivamente, o interesse político não se identifica mais com a promoção de toda a comunidade, como no passado helênico, mas sim com a ordem mercantil e a acumulação de capital.

O dinheiro, portanto, vem a ser outro componente central na formação do poder do Estado moderno. A arquitetura aglutinadora das forças modernizadoras sustenta que nação, Estado e moeda devem ser congruentes, conforme o princípio "uma nação, um Estado, uma moeda". Ou seja: se a cada nação corresponde um Estado, por sua vez a soberania nacional tem na moeda própria um dos seus principais marcos. A fortíssima vinculação entre estes elementos ainda hoje é atual, em que pese a crescente globalização e desterritorialização ${ }^{12}$. São "inseparáveis", já desvendava Polanyi, ligando o estabelecimento da nação como unidade política à constituição do meio circulante nacional (1980, p. 203).

Enquanto a moeda circulava como ouro/prata, ela não ficava restrita a fronteiras, ainda que tenha imagens deste ou daquele soberano. A forma papel, por ter validade dentro de estritos limites, reforça a ideia de soberania do Estado sobre um determinado território, permitindo a potencialização do Estado. Assim como uma bandeira ou um hino, uma moeda doméstica simboliza e confirma um senso

\footnotetext{
${ }^{11}$ Clark, apud Giddens (2008, p. 127).

${ }^{12}$ A finança global contemporânea completa o processo de autonomização do econômico, agora liberando-se das amarras políticas estatais. Se antes o território continha o dinheiro, na dupla acepção do verbo conter, o dinheiro global, desnacionalizado, flui em redes cada vez mais abstratas, e deixa de ser regulado geograficamente. Hoje, impõe-se o dinheiro em estado puro, cuja ação cega gera ingovernabilidades, alerta Milton Santos (2001, p. 101). Sobre a atual inadequação do modelo westfaliano (centrado no Estado) de gestão monetária consultar Cohen, "A geografia do dinheiro".
} 
de nacionalidade: "as estampas da moeda constituem um projeto de identidade nacional”, comenta Janine Ribeiro ${ }^{13}$.

Há aqui o perfeito casamento de dois elementos divinos cuja vigência exige plena fé $^{14}$... A soberania apenas se completa quando a moeda a ela se subordina. Não por acaso, surgem, simultaneamente, na França revolucionária, o Estado-nação e o papel moeda, emitido pelo mesmo" ${ }^{15}$ " Quem realiza o sonho hobbesiano da soberania não é o monarca absoluto, mas os jacobinos. A soberania chega a seu auge quando se proclama soberania popular", arremata Janine Ribeiro (2009, p. 153).

A fusão ideológica do Estado com o povo é propiciada pelo caldeirão revolucionário francês guilhotina e poda toda diferença ${ }^{16}$, produzindo uma identificação total, visceral, dos cidadãos com a megamáquina de poder. É somente com a máscara da conquista do Estado pela nação (ARENDT, 2011, p. 261), emblematizada pela revolução francesa e o advento do Estado-Nacional, que se introduz o serviço militar patriótico e obrigatório, formando-se exércitos regulares que permitem o Estado atingir sua máxima força, tornando arcaicas as caras tropas de mercenários que muito limitavam a atividade guerreira. A lealdade à pátria é uma coação afetiva e mais que efetiva. Ao fazer do cidadão, soldado, nação e exército tornam-se "dois lados da mesma moeda", esclarece Nisbet (1982, p. 87).

Ainda que sempre tenha havido guerras (o que está esculpido no aforismo de Heráclito: "a guerra é o pai de todas as coisas") - e elas continuam a ocorrer ${ }^{17}$ -

${ }^{13} \mathrm{~A}$ inocente invenção da fotografia e sua difusão comercial no final do século XIX também contribuiu decisivamente para a consolidação do Estado nacional, pois deu credibilidade ao passaporte, tornando-o um decisivo dispositivo de poder que possibilitou o controle fronteiriço, atividade de vigilância vital para que esta formação estatal se completasse.

${ }^{14}$ O caráter mágico do dinheiro foi exponenciado quando da introdução da moeda papel, fiduciária. John Law, pioneiro deste processo e grande especulador do início do século XVIII, dizia que "eu descobri que o segredo da pedra filosofal é fazer ouro do papel" (FERGUSON, 2009, p. 132). Fiat Money: isto levará os primeiros economistas substituírem os alquimistas como consultores do rei nas cortes, revela Binswanger (2011, p. 83).

${ }^{15}$ A emissão dos "assignats", que excedia a qualquer razoabilidade, está associada à embriaguez terrorífica do período jacobino, cujo caos apenas se resolve com a criação do Banco da França por Napoleão, avalia Gustavo Franco (BINSWANGER, 2011, p. 184).

${ }^{16}$ Cf. Maffesoli (2001, p. 294). A guilhotina é, portanto, a grande metáfora do Estado nacional.

${ }^{17}$ Fazendo um balanço do vasto conhecimento acumulado pela antropologia, psicologia, biologia e pela neurociência, bem como de suas próprias pesquisas com psicologia animal, Frans de Waal demonstra que a tese de sermos uma espécie de "primatas assassinos" é um falso mito. Estaríamos mais próximos de ser "primatas bipolares", pois tanto temos a amabilidade dos bonobos, quanto a brutalidade do chimpanzé. Avalia ainda que "a guerra parece ter mais relação com o poder e os ganhos do que com os impulsos agressivos" (2010, p. 287; 44). A evolução 
uma profunda e decisiva novidade surgiu nesta aurora do mundo moderno: a guerra sai da pequena escala e se torna total, envolvendo "não apenas forças militares, mas nações inteiras: todos os recursos de uma nação contra todos os recursos de outra nação" (NISBET, 1982, p. 69). Quem primeiro visualizou isto foi Maquiave ${ }^{18}$, cuja maior contribuição é vislumbrar "a firme união do militar ao político" e apontar para a necessidade de exército de cidadãos. A política, para Maquiavel, é "tanto uma extensão da prática militar, quanto esta é uma extensão da política". A Revolução Francesa apenas expandirá os limites do exército povo, da pequena cidade-Estado para o de todo um país. Como é sabido, o conceito de guerra total será desenvolvido por Clausewitz através da sua tese central da "inseparabilidade entre guerra e política” (NISBET, 1982, p. 72-87).

Weber (1979, p. 301) salienta ainda que a obediência contida nos exércitos regulares "deu origem a toda disciplina", favorecendo em particular a grande escala da arregimentação industrial. Ou seja, o canhão terá "profundas consequências na feição da civilização moderna”, sintetiza Giddens (2008, p. 132).

$\mathrm{Na}$ era moderna, portanto, guerra e política se confundem face sua idêntica natureza e concepção, fenômeno que Foucault (2005, p. 22) também expressa quando define política como "a guerra continuada por outros meios", confirmando que a máxima de Clausewitz tem duas indistintas faces, tal como um laço de Moebius. Desse modo, "o Estado moderno planeja a guerra. A guerra, mais que o crescimento, tornou-se a saúde do Estado" (WOLFE, 1985, p. 209), impulsionando o Ocidente a conquistar "O mundo não por causa da superioridade de suas próprias ideias, valores ou religião, mas pela superioridade demonstrada na aplicação da violência organizada", avalia Huntington. Sublinha Arrighi (2008, p. 106) que a proeminência do caminho europeu em relação ao asiático-oriental está na "sinergia entre as capacidades financeira e militar", sintetizando um dos eixos do presente texto. O peso atual do orçamento militar não mente: nossa civilização é dominada pela guerra, origem de todos os Estados.

Em contraste com o espírito proselitista, universalista e beligerante do judaísmo/cristianismo e sua noção de povo escolhido, a China, guiada por "princípios confucianos, desprezo pelo militarismo e, em menor grau, pelo comerciante" (GIDDENS, 2008, p. 130), queimará, no começo do séc. XV, sua imensa esquadra. Como "nem o hinduísmo, nem o confucionismo, acreditam em mandamentos universais ou na necessidade de difundir a fé" (ZAKARIA, 2008, p. 95), nem Índia nem China portam um sentimento de destino. "A ilusão do destino cria violência no mundo, tanto através de omissões, quanto de missões", afirma o nobel A. Sen (2007, p. 17).

nos dotou do mecanismo da empatia, conclui, confirmando a tese que Adam Smith expos na "Teoria dos sentimentos morais".

${ }^{18}$ Que também publicou a obra “A arte da guerra”, em 1521. 
O coroamento da nação pelo Estado tipifica o modelo estatal ocidental que se consolida na Europa no início do século XIX, no qual o elemento nacional é critério de legitimidade do Estado. Declara Hegel, então, que o Estado, por dispor da força da razão, configurará a "Razão em ato", a suprema e mais perfeita realidade, a própria materialização do "espírito do mundo". A sua formação, portanto, permite conhecer, finalmente, o devir que orienta e dá sentido à história universal ${ }^{19}$. Considerando que a historicidade ou a vitalidade de um povo depende da capacidade da nação de vir a ser Estado, Hegel definirá que existem "povos com história" e "povos sem história", binômio com que demonstrará o triunfo dos europeus, os quais culminam a marcha da humanidade, difamando e depreciando os povos não europeus. Ao conceber que "a história do mundo é o próprio tribunal do mundo", Hegel professa que em cada época somente uma nação representa o espírito do mundo, tendo o direito de governar as demais. Assim, pretensamente superior, neste momento a civilização eurocêntrica encarna o espírito e deve colonizar os povos "incultos", levando a eles a possibilidade de aceder à história, ao progresso e à humanidade plena (ver notas 40 e 41).

A ficção nacional que emerge a partir do fim das Guerras Napoleônicas e celebra a nova compreensão do "povo como nação", vai se entrelaçar com a então emergente ideia "científica" do "povo como raça", permitindo vincular nação e raça e afirmar a tese da "nação plenamente racializada" (APPIAH, 1997, p. 80). Convictos de sua unidade biológica essencial e superior, irrompem os movimentos pan-europeus com sua messiânica missão de dominarem o mundo não branco para aperfeiçoarem a espécie humana em busca de uma salvação temporal. Mannheim (1972, p. 78) viu que a solidariedade interna das nações-Estado repousa no sentimento ampliado de sermos "nós mesmos", e que a lealdade a esta forma moderna de unidade grupal se nutre do "desejo de gozar da soberania" e do "sentimento de uma missão especial a cumprir na esfera política".

Derivada de "natio", nascimento em latim, em sua origem o conceito de nação não demarcava a territorialidade sobre a qual o Estado exercia sua autoridade, sendo apenas um "sinônimo de família aumentada" que atingia aqueles que viessem de uma localidade comum ${ }^{20}$, sem conotações político-territoriais. Quando os governantes definem as fronteiras do Estado como adjacentes ao espaço de um determinado grupo étnico, dando a todo o território um mesmo caráter nacional, estes dois conceitos se fundem como Estado-nação, com um poder muito mais

\footnotetext{
${ }^{19}$ Conforme analisa Cassirer (2003, p. 312), Hegel imaginava a história governada por leis universais onde aos indivíduos apenas resta se submeter como marionetes, sendo o autor e dramaturgo da tragédia histórica a "ideia divina".

${ }^{20}$ O nacionalismo "não existiu muito antes do século XVI", registra Nisbet (1982, p. 142). Habermas (2000, p. 298) assinala que na Idade Média a origem nacional demarcava pejorativamente o estrangeiro, diferenciando-o do homem da terra. Hodiernamente, esta polaridade inverteu-se.
} 
total, pois a família/comunidade - nível onde brota a dimensão quente da cultura, e lócus, portanto, da nação - torna-se indistinguível do Estado, que espelha ser uma espécie de "família ampliada", deslocando-a e substituindo-a. Sem a mediação da família ou de uma comunidade, fomos individualizados e uniformizados. O ser humano passa a ser visto apenas como "homem natural" que, livre e racional, se vincula diretamente ao Estado através do culto de seus símbolos pátrios (bandeira, hino...), onde se entrelaça em algum grau de solidariedade com outros indivíduos até então estranhos.

Diferentemente da família ou de outros níveis de associação de vizinhança, onde de fato todos nos formamos, o Estado, estrutura burocrática, pertence a um sistema interestatal, no qual prevalece a hierarquia piramidal de poder, uma ordem militar mundial sempre definida belicamente. A sua soberania não é absoluta, portanto, pois, dada sua natureza internacional e geopolítica, ele nunca foi uma entidade política autônoma. Em contrapartida ao novo padrão de guerra, estabelece-se um "novo padrão de paz" (GIDDENS, 2008, p. 272), ou seja, uma organização global de Estados que se reconhecem mutua e reflexivamente, perfazendo um "gigantesco autômato" onde "nações e povos eram apenas bonecos", ironiza Polanyi (1980, p. 215).

Mas é este Estado que se torna avatar de uma determinada cultura investida como imagem de toda uma região, institucionalizando-a e folclorizando-a. Ele, ao absorvê-la, necessariamente distorce-a, pois opera no plano geopolítico. No mesmo momento em que se simula a conquista do Estado pela nação, ela dissolve-se na sua fria burocracia. Ou seja, o Estado-Nação é simplesmente a sociedade de Estado que, ao impor uma coesão cada vez maior e centralizada em um amplo território pela projeção da nação sobre o mesmo, na prática suprime $\mathrm{a}(\mathrm{s})$ nação(ões) $)^{21}$, que passa a figurar apenas como um disfarce para promover os interesses das elites ${ }^{22}$. A nacionalidade é exatamente um dispositivo de poder que encobre com uma aura de legitimidade "nacional" as práticas de colonialidade e subalternidade vigentes, as quais ficam naturalizadas, uma vez que nela todos fazemos parte da mesma "comunidade de destino". Assim, sacrifícios se aquiescem orgulhosamente, pois agora em nome da "nação".

O recrutamento obrigatório e a existência do exército-povo, desencadeando a guerra ilimitada, indicam que não só a propriedade e a riqueza estão a serviço do

21 Quotidianamente o termo "nação" surge como sinônimo de "Estado", como em "Organização das Nações Unidas", e nos inúmeros usos da expressão "internacional". Esta ausência de distinção terminológica revela o quanto as instituições políticas e o imaginário social gravitam em torno do Estado.

22 "As classes dominantes têm muito menos dificuldade de representar suas próprias políticas como sendo de 'interesse nacional"'. (Giddens, 2008, p. 238). 
Estado, mas, acima de tudo, toda a vida humana. Com o Estado-nação, a condição de nascimento - a vida nua - torna-se, pela primeira vez, o princípio de legitimidade da soberania e o fundamento do Estado. Assim, a política se torna pura biopolítica e o poder soberano pode governar os homens de modo absoluto (Agamben). O milenar ideal de humanidade e dignidade do homem anunciado há séculos (como por Saint Victor no sec. $\mathrm{XII}^{23}$ ) será devorado pelo tribalismo e racismo dos movimentos de unificação: "nenhuma igualdade subsiste quando o indivíduo deve o seu valor apenas ao fato de ter nascido russo ou alemão", expressa Arendt (2011, p. 266).

Se a vida por si só define a soberania, isto significa que há vidas dignas e vidas indignas (e estas podem ser eliminadas). Detendo o monopólio da violência, o soberano é aquele que decide "qual vida pode ser morta sem que se cometa homicídio" (AGAMBEN, 2002, p. 149). Assim, a determinação de quem é cidadão (quem é - e quem não é - alemão, por exemplo) vai definir limiares e separar, progressivamente, não apenas os que têm solo (ius soli) e sangue (ius sanguinis), mas também opera eugenicamente como um cordão sanitário, segregando por critérios de gênero, idade, pele, religião, renda; excluindo mulheres, jovens, hebreus, doentes mentais, idosos e pacientes em vida vegetativa...

O amor à terra natal e aos conterrâneos é um elemento profundo da psique humana, descortina Mumford. Todos somos etnocêntricos e achamos nosso próprio grupo étnico mais importante que os demais. Todavia, "se toda cultura é etnocentrista, somente a ocidental é etnocidária", proclama Clastres (1982, p. 56). Nossa vocação supressora das diferenças, julgadas inferiores e más, é uma extensão de certo tipo de formação estatal que engendrará as contemporâneas sociedades de Estado. Quando "as cândidas emoções e sentimentos puros que prendem os homens à sua aldeia” (MUMFORD, 1958, p. 400) transformam-se em princípio definidor do Estado, ele passa a unificar e purificar toda uma vasta região, até então diversa, com uma única identidade nacional. Esta, fundada na identificação narcísica com os que se assemelham a um determinado padrão (de língua, cor, religião), naturalmente vai se contrapor às nacionalidades rivais, facilmente transbordando em animosidades telúricas e atávicas. A política, ao se organizar exclusivamente ao redor desta forma de Estado, gera intolerância e deterioração entre as miríades de comunidades idiossincráticas e multiculturais presentes em qualquer agrupamento humano, produzindo a vivissecção do tecido social (Gandhi) ${ }^{24}$.

\footnotetext{
23 "Quem acha doce a terra natal ainda é um tenro principiante; aquele para quem toda terra é natal já é forte; mas é perfeito aquele para quem o mundo inteiro é um lugar estrangeiro".

24 "Hoje em dia ninguém é uma coisa só. Rótulos como indiano, mulher, muçulmano ou americano não passam de pontos de partida que, seguindo-se uma experiência concreta, mesmo que breve, logo ficam para trás. O imperialismo consolidou a mescla de cultura e identidades
} 
A ideia do moderno Estado mono-nacional fundado num "ethos nacional" leva a soberania nacional a se basear em um "genius étnico", como se o Estado pudesse encarnar uma nebulosa "alma nacional". Ora, não há essências exclusivas e originais, pois todas identidades são híbridas, dinâmicas, interativas (espelham-se para poderem se afirmar), além de inventadas, inexistindo ontologicamente de forma eterna, imutável e monolítica. Apoiar-se em tal idealização patriótica fornece a base para o surgimento de "identidades predatórias que reivindicam a extinção de outra coletividade para sua própria sobrevivência", alerta Appadurai (2009, p. 14; 46). As experiências totalitárias, especialmente a nazista, não são nenhuma aberração, mas frutos da exacerbação da intrínseca virulência nacionalista contida no conceito tribal de "nação". Representam a "tentativa patológica de fazer surgir um povo uno e homogêneo" (ROSANVALLON, 2010, p. 72), são produto da "hipnose nacionalista", a culminância da "barbárie ligada à ideia de nação" monoétnica que germinou na Europa ocidental25, expressam o lado bárbaro de nossa civilização.

"Toda cultura vive da sua própria diversidade, diz-se sempre no plural", compreende Mia Couto (2011, p. 164). Esta inautenticidade é confirmada amplamente na literatura historiográfica-cultural e antropológica que declara não existir tradições autênticas: são todas inventadas; bem como na clássica fórmula expressa por Renan da nação ser "le plebiscite de tous les jours". Isto é muito evidente tanto na formação do Estado nacional na América Latina decorrente de artifícios e idiossincrasias de lideranças crioulas que são exatos avatares co-culturais dos governantes europeus ${ }^{26}$; quanto no continente africano, onde o sentimento nacional criou-se "dentro dos retângulos perfeitamente arbitrários que os impérios europeus traçaram sobre o mapa da África”, desenhados sobre areias, águas e mangues $^{27}$. Em todos estes casos onde a geografia nacional pós-colonial deixou

numa escala global. Mas, seu pior e mais paradoxal legado foi permitir que as pessoas acreditassem que eram apenas, sobretudo, exclusivamente brancas, pretas, ocidentais ou orientais" (SAID, 2011, p. 510). Do mesmo modo, Todorov (2010, p. 106) argumenta que "cada indivíduo é portador de múltiplas culturas".

${ }^{25}$ Morin (2009: 73; 66). "O que não se perdoa em Hitler não é o crime em si, o crime contra o homem [...] mas o crime contra o homem branco e ter aplicado à Europa procedimentos colonialistas", acrescenta Césaire (2008, p. 316).

${ }^{26}$ Defende Octavio Paz que "as novas repúblicas foram inventadas por necessidades políticas e militares do momento, não porque expressassem uma verdadeira peculiaridade histórica. Os "traços nacionais" se foram formando mais tarde, em muitos casos são apenas consequência da prédica nacionalista dos governos. Mesmo agora, um século e meio depois, ninguém pode explicar satisfatoriamente em que consistem as diferenças "nacionais" entre argentinos e uruguaios, peruanos e equatorianos, guatemaltecos e mexicanos. E também nada - salvo a persistência das oligarquias locais, mantidas pelo imperialismo norte-americano - explica a existência na América Central e nas Antilhas de nove repúblicas” (2006, p. 111).

${ }^{27}$ Robinson (1971, p. 60). O testemunho de Amadou Hampate Ba, ex-embaixador do Mali, é mais que revelador: "O conceito de nação é um conceito moderno, de importação ocidental. A 
Estados à procura de nações, o novo Estado-nacional é uma clara expressão da colonialidade do poder regente destes países, uma espécie de colonialismo interno que dá continuidade direta ao antigo colonialismo europeu ${ }^{28}$.

África conheceu Estados, reinos, impérios, mas não "nações" no sentido geográfico e moderno da palavra. Os grandes conjuntos que se reivindicava e aos quais se sentia pertencer eram as etnias. Estas, muitas vezes móveis, podiam cobrir vastos territórios. Um peul do Macina podia viajar para a Costa do Marfin; lá encontrava outros peúles, e se sentia em família. Um senufo da Costa do Marfin que viesse para o Mali encontrava os seus. Cada grande cidade comportava bairros consagrados às diferentes etnias, de maneira que o viajante tinha certeza de sempre encontrar nelas os seus irmãos. [...] Os peúles eram cidadãos de Gana, mas continuavam regidos pela lei peul [...]. O ideal seria uma espécie de "Estado de etnias unidas", em que cada etnia conservaria suas particularidades, em que seus problemas internos seriam resolvidos pelas leis consuetudinárias, enquanto uma lei geral válida para todos manteria o funcionamento harmonioso do conjunto" (1989, p. 144). Said, nascido na Palestina em 1935, também relata que até sua adolescência se viajava do Líbano até Egito sem maiores dificuldades, o que hoje é impossível. Agora o nacionalismo árabe "tem se dividido em unidades cada vez menores. [...] Os nacionalismos de Estado se fragmentam em nacionalismos de clã ou de seita". A absolutização da identidade "acima do conhecimento a respeito dos outros", politizando-a ao extremo, está levando a sociedade civil (universidades, meios de comunicação e a cultura em sentido amplo) a ser "tragada pela sociedade política" (2011, p. 455-456).

${ }^{28}$ Face ao fracasso na construção de muitos destes Estados, o Ocidente cunhou o eufêmico conceito de "Estados fracos ou falidos" (como se o ideal fosse um Estado forte, o que nos aproxima do auditório onde aplaudiremos o Estado totalitário). Com base nele, e numa autêntica política de "criar problemas para vender soluções", cria-se o pretexto para operações "humanitárias" e advogar o direito de ingerência, agora para ajudá-los na reconstrução estatal. Numa continuação do espírito medieval das cruzadas, faz-se uma espécie de reconquista em nome do bem. Uma convincente análise do caso africano é feita por Appiah que, indo muito além da metanarrativa fórmula do Estado-Nação, assinala a importância das estruturas políticas comunais etno-regionais em vigor na África contemporânea onde, em grande parte, o tribalismo, "longe de constituir um obstáculo ao governo, é o que possibilita qualquer forma de governo" (1997, p. 238). A vigência do direito consuetudinário, as lealdades tradicionais e a densa trama de organizações não governamentais, assumindo as funções estatais, explicam o retraimento do Estado, o qual se resigna a ser um "facilitador" do que um dirigente centralizador. Num contexto onde a democracia "não é uma simples questão de parlamentos e eleições", e onde "é o Estado que precisa de democracia, mais do que os cidadãos", aponta que a "persistência dessas afiliações "pré-modernas" indica "a inadequação do modelo do Estado nacional" (ibid., p. 239). Nos países outrora colônias, profundos ressentimentos hoje afloram ao lado do renascimento identitário, envolvidos com fanatismo e racismo, constata Ziegler (2011) após percorrer o mundo como Relator de Direitos Humanos da ONU entre 2000 e 2008. Reportando-se aos países árabes, Memmi percebeu já em 2004 que nos mesmos o Estado-nação "se esgotou antes de se afirmar plenamente", e que do "fim do ideal nacional" emerge a visão integrista do califado islâmico em toda região (2007, p. 82). A indigenidade, quando cruza com intolerâncias religiosas, "adquire uma força fascista, misógina", observa Mary Pratt (2010, p. 443). Vale destacar que o conceito "colonialidade", de Aníbal Quijano, que descortina a matriz racial da subalternidade e desigualdade hodierna, aglutinou a corrente decolonial, na qual destacamos também Walter Mignolo e Santiago Castro-Gómez. 
Sabedor de que a peruanidade "é uma coisa por criar", pois "somos uma nacionalidade em formação”, Mariátegui (1988, p. 227; 301) observou que a nação é uma poderosa "alegoria" 29 útil para o processo da revolução socialista, urgente missão com a qual está comprometido, pois proporcionará o instrumento que mobilizará e unificará politicamente os índios ${ }^{30}$. Similarmente, mas com outro sinal ideológico, Massimo d'Azeglio, um dos mentores da unificação, reconhecendo que nada havia de primordial na italianidade, admitiu: "Fizemos a Itália, agora temos de fazer os italianos". Por esta razão, endossamos a conclusão de Merquior: "o nacionalismo não se origina de nações; na verdade, é mais comum que ele as faça nascer”. (1981, p. 9).

Mais contemporaneamente, diante do ressurgimento do nacionalismo intolerante e xenofóbico com a dissolução do império soviético, Zizek (2015, p. 158-165) adverte que os atuais jogos geopolíticos manobram grotescamente a paixão nacionalista como "ferramenta de poder" de forma a fazer aproximar "uma nova Idade das Trevas", não apenas no Leste europeu, mas "dos Bálcãs à Escandinávia, dos Estados Unidos a Israel, da África Central à Índia”. Confirmando-se como um "receptáculo apertado e rancoroso de poder", cf. descreveu Tagore (Apud SAID, 2011, p. 338), a nacionalidade tem sido um sentimento manipulado por interesses os mais díspares e até completamente opostos, mas todos salvacionistas.

"My country, right or wrong". Ao contrário do que Mannheim assinalou logo após a Segunda Grande Guerra, a "obediência incondicional ao demônio de poder da soberania nacional e do nacionalismo agressivo" (1972, p. 86) não é uma mera

29 “A nação mesma é uma abstração, uma alegoria, um mito, que não corresponde a uma realidade constante e precisa, cientificamente determinável" (ibid., p. 210).

${ }^{30}$ Ao reconhecer que os índios são "o cimento da nacionalidade", também aponta que "lhes falta vinculação nacional. Seus protestos têm sido sempre regionais" (ibid., p. 303; 45). Já no prólogo à "Tempestad en los Andes", de Luís Valcárcel, retomado nos "Siete Ensayos", Mariátegui explicitou que sua "fé no ressurgimento indígena" provém a "ideia de revolução socialista”, pois "a esperança indígena é absolutamente revolucionária” (ibid., p. 322).

Não há dúvida que o nacionalismo, de modo geral, alavancou as lutas anticoloniais e de libertação. Fanon, todavia, percebendo que o processo de descolonização vai muito além da construção nacional (esta é uma etapa necessária daquele), além dos riscos da mera substituição das elites dirigentes sem modificar profundamente a subalternização das pessoas (não é mera coincidência que os "libertadores" apresentam-se fardados, acrescento eu), nunca acreditou nas certezas heroicas do mesmo. Sem ilusões, explica que "a nação não existe em parte alguma senão num programa elaborado por uma direção revolucionária [...]. O nacionalismo, se não se torna explícito, se não é enriquecido e aprofundado, se não se transforma [...] em humanismo, conduz a um beco sem saída” (1968, p. 206; 166-167).

Ciente do efeito corrosivo do nacionalismo, Jean Genet adota uma postura crítica ainda mais forte: "no dia em que os palestinos se institucionalizarem, já não estarei ao lado deles. No dia em que os palestinos se tornarem uma nação como qualquer outra, não estarei mais com eles" (citado em NEGRI; HARDT, 2001, p. 126). 
"etapa" que será superada pela prosperidade global e advento da consciência da interdependência entre os países. Ela ressurge a todo instante provocada pelos mais diferentes eventos (inclusive desportivos) e alimentada por jogos e manobras do poder. Os impulsos histéricos do nacionalismo militante moderno estão sempre latentes e presentes e serão insuperáveis enquanto o Estado-Nacional for o princípio organizador da política.

Num mundo em que as diferenças circulam e se encontram cada vez mais, fazer da identidade a matriz ideológica do político é transformar as divisões culturais, étnicas e religiosas em linhas de fratura que antagonizam acirradamente os etéreos e artificiosos particularismos da narração da nação, levando a regressivos embates identitários. As identidades não são um fenômeno ontologicamente determinado, pois elas não se constituem de forma insularizada, pura e eterna, mas se apresentam múltiplas, plásticas, contingentes e elegíveis. Se todos temos inúmeras filiações (cf. nota 36), qualquer concepção singularista da identidade humana é fantasiosa e de horizonte limitado, exorta Amartya Sen (2007). Ao impor-se uma identidade única, absolutizando-se narcisicamente aquilo que é fundamentalmente relacional, abrem-se raivosos e acumulativos conflitos, ao modo de guerras santas irresolúveis. No atual contexto, sustenta Safatle (2015, p. 355), é vital fazer das diferenças culturais "objeto de indiferença política", de modo que a política não seja mais pensada sob a forma da identidade e se descole da proclamação identitária: "a verdadeira política está sempre além da afirmação das identidades" (ibid., p. 364).

\begin{abstract}
$* * *$
"Se numa cidade os cidadãos não tomam as armas porque estão aterrados pelo medo, não se pode dizer que ai existe paz, e sim pura ausência de guerra. Paz. é virtude originada da força d'alma no respeito às leis. Uma cidade onde a paz. é efeito da inércia dos súditos tangidos como rebanhos e feitos apenas para servir, merece antes o nome de solidão do que de cidade". (Espinoza).

"Diz Santo Agostinho, os grandes reinos são apenas projeções aumentadas de pequenos ladrões”. (Negri; Hardt).

"Nunca em minha vida amei a povo ou coletivo algum, nem ao alemão, nem ao francês, nem ao norte-americano, nem tampouco à classe operária on qualquer coisa deste tipo. Em realidade, apenas amo meus amigos e me sinto completamente incapaz de qualquer outra classe de amor". (H. Arendt).
\end{abstract}

Assim, a irrupção dos pobres; a violência crescente dos Estados nascentes e suas guerras religiosas, étnicas e ideológicas; bem como a exploração colonialista dos 
povos considerados inferiores, passam a reger a vida social. Paulatinamente, a modernidade transitou de uma primeira para uma segunda fase, como fica visível na passagem do domínio ibérico para a hegemonia britânica, retrato da mudança de um modo de ser moderno, barroco, para outro, cartesiano. Este processo em parte também foi afetado por acasos naturais e estratégias militares erráticas, presentes na crucial e determinante derrota da grande armada ibérica em 1588.

Com a vida em comum tendo como fundamento a trindade (i) medo, (ii) competição, (iii) violência, as virtudes civis mostram-se incapazes de governar e manter a paz, e a justificação antropológica-política da sociedade fundada na heteronomia vence a autonomia. Isto é, o pensamento de Maquiavel e Hobbes alavanca o Tratado de Westphalia de 1648, sobrepujando a revolução humanista e aristotélica de Erasmo e Espinoza, o que não significa a desqualificação da potência desta, mas sua inadequação na ocasião para conter as forças vulcânicas então despertas.

As noções de economia, contrato, vontade geral, cidadão, prescindem do dispositivo de um rei com mandato divino para justificar a devoção ao poder e a sujeição à ordem heterárquica. Deste modo, ao aceitar a soberania, agora "democrática"; e o mercado, enfim solto, autômato e insubmisso a polis, os processos emancipatórios em curso que rompiam com a plena arbitrariedade do poder e fundavam a potência da multidão ficam restringidos, limitando a capacidade de invenção do futuro.

Como nos moldamos entre a finitude e a transcendência, a individualidade e a comunidade, exercemos uma liberdade que, se não é absoluta, tampouco é maniqueísta ou estreita (cf. nota 1). Se ambições fáusticas desmedidas são ilusórias, também não estamos aprisionados na jaula weberiana, nem a história já está escrita, como acreditou Marx ao recorrer ao aforismo "de te fabula narratur". Não estamos a salvo de acontecimentos imprevisíveis ou acima das coerções naturais, muito menos conduzidos por mandato providencial ou leis inexoráveis. Mas, mesmo diante das incertezas do futuro desconhecido, nosso destino depende da nossa vontade.

\section{Referências}

AGAMBEN, G. Homo Sacer. Belo Horizonte: Ed. UFMG, 2002.

AGAMBEN, G. O reino e a glória. São Paulo: Boitempo, 2011.

APPADURAI, A. O medo do pequeno número. São Paulo: Iluminuras, 2009.

APPIAH, K. Na casa de meu pai. Rio de Janeiro: Contraponto, 1997. 
ARENDT, H. A condição humana. São Paulo: Forense Universitária, 1989.

ARENDT, H. Origens do totalitarismo. São Paulo: Cia. das Letras, 2011.

ARrigHI, G. Adam Smith em Pequim. São Paulo: Boitempo, 2008.

BA, A. In: Civilizações. Entrevistas do Le Monde Diplomatic. São Paulo: Ática, 1989.

BERMAN, M. Tudo que é sólido se desmancha no ar. São Paulo: Cia. das Letras, 1987.

BINSWANGER, H. Dinheiro e magia. Rio de Janeiro: Zahar, 2011.

BOETIE, E. Discurso sobre a servidão voluntária. Lisboa: Antígona, 1986.

CASSIRER, E. O mito do Estado. São Paulo: Códex, 2003.

CÉSAIRE, A. Discurso sobre el colonialismo. In: Para leer a Aimé Césaire. México: FCE, 2008.

CLASTRES, P. Do etnocídio. In: CLASTRES, P. Arqueologia da violência. São Paulo: Brasiliense, 1982.

COUTO, M. E se Obama fosse africano? São Paulo: Cia. das Letras, 2011.

DUBY, G. Lição de História. Veja: reflexões para o futuro. São Paulo: Abril, 1993.

FANON, F. Os condenados da terra. Rio de Janeiro: Civilização Brasileira, 1968.

FERGUSON, N. A ascensão do dinheiro. São Paulo: Planeta, 2009.

FOUCAULT, M. Em defesa da sociedade. São Paulo: Martins Fontes, 2005.

FROMM, E. O medo à liberdade. Rio de Janeiro: Guanabara, 1986.

GIDDENS, A. O Estado-Nação e a violência. São Paulo: Edusp, 2008.

GOFF, J. Por amor às cidades. São Paulo: Unesp, 1998.

GRAY, J. Cachorros de palha. São Paulo: Record, 2009. 
HABERMAS, J. Realizações e limites do Estado nacional europeu. In: BALAKRISHNAN, G. (Org.). Um mapa da questão nacional. Rio de Janeiro: Contraponto, 2000.

HIRSCHMAN, A. A moral secreta do economista. São Paulo: Unesp, 2000.

KUNTZ, R. Capitalismo e natureza. São Paulo: Brasiliense, 1982.

LISBOA, A. Economia, idolatria, charlatanice. A inelutável dimensão religiosa do paradigma econômico. Studium, Curitiba, n. 13, 2014.

MAFFESOLI, M. A violência totalitária. Porto Alegre: Sulina, 2001.

MANNHEIM, K. Liberdade, poder e planificação democrática. São Paulo: Mestre Jou, 1972.

MARIÁTEGUI, C. Siete ensayos de interpretación de la realidad peruana. México: Era, 1988.

MEMMI, A. Retrato do descolonizado. Rio de Janeiro: Civilização Brasileira, 2007.

MERQUIOR. A teoria social da transição. In: GELLNER, E. Nacionalismo e democracia. Brasília: Ed. UnB, 1981.

MILBANK, J. Teologia e teoria social. São Paulo: Loyola, 1995.

MIRANDOLA, G. Pico Della. A dignidade do homem. São Paulo: Escala, s.d.

MORIN, E. Cultura e barbárie europeias. Rio de Janeiro: Bertrand Brasil, 2009.

MUMFORD, L. A condição do homem. Porto Alegre: Globo, 1958.

NEGRI, A.; HARDT, M. Império. São Paulo: Record, 2001.

NISBET, R. Os filósofos sociais. Brasília: Ed. UnB, 1982.

NOBRE, M. Depois da 'formação'. Piauí, n. 74, novembro de 2012.

PAZ, O. O labirinto de solidão. Rio de Janeiro: Paz e terra, 2006.

PETTY, W. Tratado dos impostos e contribuições. São Paulo: Abril, 1983. 
POLANYI, K. A grande transformação. Rio de Janeiro: Campus, 1980.

PRATT, M. La indigeneidad hoy. In: CADENA, M. de la; STARN, O. Indigeneidades contemporáneas: cultura, política y globalización. Lima: IEP, 2010 .

RAMOS, A. G. A nova ciência das organizações. Rio de Janeiro: FGV, 1981.

RIBEIRO, R. A realidade contra-ataca? In: COSENZA, C. A.; DORIA, F. A. Crise na economia. Rio de Janeiro: Revan, 2009.

ROBBINS, L. Um ensaio sobre a natureza e a importância da Ciência Econômica. São Paulo: Saraiva, 2012.

ROBINSON, J. Liberdade e necessidade. Rio de Janeiro: Zahar, 1971.

ROSANVALLON, P. Por uma história do político. São Paulo: Alameda, 2010.

SAFATLE, V. O circuito dos afetos. São Paulo: Cosac Naify, 2015.

SAHLINS, M. La ilusión occidental de la naturaleza humana. México: FCE, 2011.

SAID, E. Cultura e imperialismo. São Paulo: Cia. das Letras, 2011.

SANTOS, M. Por uma outra globalização. São Paulo: Record, 2001.

SEN, A. Identidade e violência. Lisboa: Tinta da China, 2007.

SMITH, A. Riqueza das nações. São Paulo: Abril, v. II, 1983.

TAWNEY, R. A religião e o surgimento do capitalismo. São Paulo: Perspectiva, 1971.

TODOROV, T. O medo dos bárbaros. Petrópolis: Vozes, 2010.

WAAL, F. A era da empatia. São Paulo: Cia. das Letras, 2010.

WEBER, M. O significado da disciplina. Ensaios de sociologia. Rio de Janeiro: Zahar, 1979.

WOLFE, A. Política perversa e guerra fria. In: THOMPSON, E. P. et al. Exterminismo e guerra fria. São Paulo: Brasiliense, 1985. 
ZAKARIA, F. O mundo pós-americano. São Paulo: Cia. das Letras, 2008.

ZIEGLER, J. O ódio ao Ocidente. São Paulo: Cortez, 2011.

ZIZEK, S. Problema no paraíso. Rio de Janeiro: Zahar, 2015.

Endereço para correspondência:

Armando de Melo Lisboa - amelolisboa@gmail.com

R. Eng. Agronômico Andrei Cristian Ferreira, s/n, Trindade

88.040-900 Florianópolis/SC, Brasil 